\title{
PENINGKATAN HASIL BELAJAR PESERTA DIDIK MELALUI MODEL PEMBELAJARAN KOOPERATIF TIPE MIND MAPPING DENGAN APLIKASI MICROSOFT TEAMS PADA PELAJARAN SOSIOLOGI MATERI MASALAH SOSIAL KELAS XI IPS SEMESTER GASAL DI SMA N 1 JEKULO KUDUS TAHUN PELAJARAN 2020 / 2021
}

Oleh:

Eko Purnomo ${ }^{1}$

\begin{abstract}
Abstrak
Penelitian ini bertujuan untuk mengetahui pelaksanaan penerapan model pembelajaran Kooperatif Mind Mapping dengan Aplikasi Microsoft Teams yang dapat meningkatkan hasil belajar peserta didik pada mata pelajaran sosiologi kelas XI IPS di SMA N 1 Jekulo Kudus tahun Pelajaran 2020/2021. Penelitian dilaksanakan dalam dua siklus yang terdiri dari tahap perencanaan, pelaksanaan, pengamatan, dan refleksi. Siklus I terdiri dari dua pertemuan yang terdiri dari pelaksanaan pembelajaran dan evaluasi, Demikian pula halnya dengan Siklus II yang terdiri dari satu pertemuan meliputi pelaksanaan pembelajaran dan evaluasi. Data aktivitas peserta didik digali dengan lembar pengamatan aktivitas peserta didik, data pengelolaan pembelajaran oleh guru digali dengan lembar pengamatan pengelolaan pembelajaran, sedangkan data hasil belajar peserta didik digali dengan tes hasil belajar. Hasil penelitian menunjukkan bahwa hasil belajar peserta didik selalu mengalami peningkatan dari pra siklus sampai dengan siklus II yaitu, pra siklus $(61,76 \%)$, siklus I $(73,53 \%)$ dan pada siklus II $(84,12 \%)$. Hal ini membuktikan bahwa penerapan model pembelajaran Kooperatif Mind Mapping dengan Aplikasi Microsoft Teams dapat meningkatkan hasil belajar peserta didik pada mata pelajaran sosiologi kelas XI IPS di SMA N 1 Jekulo Kudus.
\end{abstract}

Kata Kunci : Aplikasi Microsoft Teams, Hasil Belajar, Mind Mapping

\footnotetext{
${ }^{1}$ Guru Sosiologi di SMAN 1 Jekulo Kudus, email: fathiyapurnomo@gmail.com
} 


\section{PENDAHULUAN}

Kurikulum 2013 menuntut perubahan pola pembelajaran yang berpusat pada guru (teacher center) menjadi pembelajaran yang berpusat pada peserta didik (student center) sehingga peran guru bukan sebagai sumber belajar utama tetapi harus bisa menjadi fasilitator, mediator, motivator dan leader selama proses pembelajaran berlangsung. Guru harus mampu mendesain pembelajaran yang kreatif dan inovatif untuk membangkitkan semangat belajar peserta didik sehingga dapat mengembangkan potensinya secara optimal sesuai dengan keterampilan dan kecakapan abad 21.

Berkaitan dengan kompleksnya materi yang harus dipelajari dalam mata pelajaran sosiologi, maka proses pembelajaran yang berlangsung harus bisa menciptakan kondisi yang kondusif sehingga peserta didik mampu mengembangkan kemampuan berpikir kritis dalam melihat fenomena sosial yang terjadi pada kehidupan masyarakat dari sudut pandang sosiologi. Salah satu cara untuk mengetahui peserta didik sudah memahami dan menguasai materi pembelajaran yang telah diajarkan yaitu dengan meningkatnya hasil belajar peserta didik. Akan tetapi dalam kenyatannya, hasil belajar peserta didik dalam pembelajaran sosiologi masih rendah. Hal ini dapat dilihat dari hasil pra tindakan yang menyatakan sebesar $55,82 \%$ siswa yang hasil belajarnya belum mencapai KKM.

Sesuai dengan pengalaman penulis dalam proses pembelajaran di kelas XI IPS di SMAN 1 Jekulo Kudus. Dimana dalam satu kelas terdiri dari 34 peserta didik yang mempunyai karakteristik yang berbeda. Berdasarkan observasi yang dilakukan peneliti, terdapat beberapa permasalahan yang menjadi sumber rendahnya hasil belajar peserta didik dalam pelajaran sosiologi, diantaranya adalah 1) peserta didik kurang memperhatikan guru saat proses pembelajaran di dalam kelas; 2) Peserta didik masih sulit memahami materi pembelajaran karena penjelasan yang disampaikan hanya mengacu pada buku teks / paket sosiologi; 3) Semangat belajar peserta didik kurang, bisa dipengaruhi oleh banyaknya aktifitas kegiatan peserta didik di sekolah ataupun karena strategi pembelajaran yang kurang menarik perhatian peserta didik; 4) Keaktifan peserta didik dalam pembelajaran masih kurang maksimal; 5) Sejumlah peserta didik masih memiliki hasil belajar yang rendah. Khususnya dilihat dari pretes awal saat pertemuan pertama untuk mengulas materi kelas XI yang sudah pernah dipelajari masih ada sebagian peserta didik yang hasilnya tidak mencapai KKM. Selain itu terdapat beberapa permasalahan yang disebabkan karena faktor guru 
diantaranya yaitu : 1) Kurangnya guru dalam menguasai kelas dan masih teacher center; 2) Belum ada kolaborasi yang tepat antara guru dan peserta didik dalam pelaksanaan KBM; 3) Guru belum menggunakan model pembelajaran yang tepat sesuai dengan keadaan kelas yang diampu; 4) Ketika menjelaskan materi guru belum memberikan contoh kasus nyata.

$\begin{array}{rrr}\text { Dengan } & \text { adanya } & \text { berbagai } \\ \text { permasalahan tersebut, diperlukan }\end{array}$
perubahan dalam proses pembelajaran yaitu dengan perubahan metode dan peningkatan peran serta peserta didik dalam kegiatan pembelajaran. Berdasarkan hasil observasi, penulis mencoba mencari pemecahan masalah untuk meningkatkan keaktifan dan hasil belajar peserta didik, maka diperoleh hasil diskusi bahwa perubahan metode pembelajaran yang di gunakan atau penyajian pembelajaran di buat lebih menarik yaitu pembelajaran dengan kooperatif mind mapping (peta pikiran). Model tersebut merupakan suatu teknik mencatat yang mengembangkan gaya belajar visual (Kurniasih dan Berlin; 2016:53). Dalam pembelajaran dengan metode ini disetiap akhir pemberian materi oleh guru, peserta didik secara berkelompok akan disuruh untuk membuat catatan dari materi tadi yaitu catatan yang mudah dipahami dan mudah diingat yakni dapat dikombinasikan dengan warna, simbol, garis, dan gambar yang sesuai dengan cara kerja otak.

Pernyataan tersebut sesuai dengan pendapat Deporter (2014: 225) yang menyatakan bahwa melalui metode mind mapping peserta didik akan merekam informasi melalui simbol, gambar, arti emosional, dan warna, persis seperti cara otak memprosesnya. Karena metode mind mapping melibatkan kedua belah otak, peserta didik dapat mengingat informasi dengan lebih mudah. Olivia (2014: 13) mengemukakan bahwa mind mapping terdiri atas tulisan, simbol, dan gambar, serta warna-warni, dengan begitu anak-anak akan menjadi kreatif. Bahkan untuk meninjau ulang materi diperlukan waktu yang singkat, sehingga waktu yang diperlukan untuk belajar menjadi lebih cepat dan efektif. Swadarma (2013: 2) menyatakan bahwa mind mapping adalah teknik grafis yang memberikan kunci universal untuk membuka potensi otak. Penggunaan mapping ini menggunakan keterampilan penyusunan kata, gambar, nomor, logika, ritme, warna, dan cara unik, sehingga dapat memberikan kebebasan kepada peserta didik untuk menjelajah luas pengetahuannya. Hal yang menjadi kajian 
dalam model Kooperatif Mind Maping ini adalah kerjasama dalam kelompok untuk membuat Mind Maping dalam pembelajaran daring terkait materi pada hari tersebut, yang dapat meningkatkan hasil belajar peserta didik.

Berdasarkan identifikasi masalah di atas, maka peneliti menentukan rumusan masalah yang akan diteliti yaitu Apakah Penerapan Model Pembelajaran Kooperatif Mind Mapping Dengan Aplikasi Microsoft Teams Dapat Meningkatkan Hasil Belajar Peserta Didik Pada Mata Pelajaran Sosiologi Kelas XI IPS di SMA N 1 Jekulo Kudus Tahun Pelajaran 2020/2021.

Tujuan dari penelitian ini adalah untuk mengetahui pelaksanaan penerapan model pembelajaran Kooperatif Mind Mapping dengan aplikasi microsoft teams yang dapat meningkatkan hasil belajar peserta didik pada mata pelajaran sosiologi Kelas XI IPS di SMA N 1 Jekulo Kudus Tahun Pelajaran 2020 / 2021. Adapun manfaat dari penelitian ini antara lain: hasil penelitian dapat menjadi contoh dan referensi tambahan bagi guru-guru dalam melakukan penelitian tindakan kelas, peserta didik, dapat digunakan untuk membantu meningkatkan keterampilan berpikir kritis dan hasil belajarnya di sekolah serta dapat menambah referensi karya ilmiah di sekolah tentang modelmodel pemecahan alternatif masalah belajar peserta didik di sekolah.

\section{METODE PENELITIAN}

Penelitian ini merupakan penelitian tindakan kelas untuk mata pelajaran sosiologi yang dilaksanakan pada siswa kelas XI IPS SMA N 1 Jekulo Kudus tahun pelajaran 2020 / 2021 yang beralamat di Jl Raya Kudus Pati Km. 10 No. 34 Jekulo Kudus. Subjek penelitian ini adalah peserta didik kelas XI IPS 3 SMA N 1 Jekulo Kudus tahun pelajaran 2020 / 2021. Kelas XI IPS 3 tersebut tersebut berjumlah 34 peserta didik yang terdiri dari laki - laki 11 orang dan perempuan 23 orang. Motivasi belajar peserta didik dalam kelas tersebut sangat beragam, ada yang mempunyai motivasi belajar tinggi, menengah dan juga rendah. Secara garis besar, terdapat empat langkah dalam melaksanakan penelitian tindakan kelas, yaitu Perencanaan (Planning) meluputi identifikasi masalah, perumusan masalah dan analisis penyebab masalah, dan pengembangan intervensi; Pelaksanaan (Acting) dilaksanakan peneliti untuk memperbaiki masalah; Pengamatan (Observing) merupakan kegiatan pengambilan data untuk memotret seberapa jauh efek tindakan telah mencapai sasaran; Refleksi (Reflecting) yaitu kegiatan mengulas secara kritis tentang perubahan yang terjadi pada siswa, suasana kelas. 
Teknik pengumpulan data yang dilakukan dalam penelitian adalah observasi, tes dan dokumentasi. Instrument yang digunakan dalam penelitian ini adalah lembar observasi (pengamatan) dan tes kemampuan kognitif. Sedangkan teknik analisis data meliputi analisis deskriptif dan analisis hasil belajar peserta didik.

Indikator keberhasilan dalam penelitian ini yaitu: (1) Indikator keberhasilan proses, dilihat dari perkembangan proses pembelajaran. Analisis ini dilakukan dengan mendeskripsikan hal-hal yang terjadi selama proses tindakan kelas pada setiap siklusnya. (2) Indikator keberhasilan produk, didasarkan atas keberhasilan kemampuan penalaran dengan menerapkan model pembelajaran Kooperatif Mind Maping. Hal ini dilakukan dengan cara membandingkan hasil pembelajaran Program Linier Dua Variabel (PLDV) sebelum dan sesudah dilakukan tindakan pada tiap siklusnya dengan batas ketuntasan minimal (KKM) adalah 70 . Selain itu, banyaknya peserta didik yang mendapat nilai kemampuan penalaran diatas KKM sebanyak lebih dari 80\%

\section{HASIL DAN PEMBAHASAN}

1. Deskripsi Siklus Pra Tindakan

Penelitian dilaksanakan di SMAN

1 Jekulo Kudus. Sebelum melakukan penelitian, peneliti melakukan persiapan persiapan yang berkaitan dengan pelaksanaan penelitian. Salah satunya tempat adalah tempat dan waktu penelitian. Pra tindakan kelas dilaksanakan pada bulan September.

Sebelum pelaksanaan tindakan kelas, peneliti memberikan penjelasan bahwa kegiatan pembelajaran yang akan dilakukan adalah kegiatan pembelajaran kooperatif tipe Mind Mapping dengan aplikasi microsoft teams. Hasil tes kemampuan penalaran awal siswa kelas XI IPS 3 SMA N 1 Jekulo Kudus sebelum adanya tindakan berdasarkan pretest yang diberikan adalah sebagai berikut:

Tabel 1 Hasil Tes pada Pra Tindakan/Siklus

\begin{tabular}{|l|l|l|l|}
\hline No & Kriteria & $\begin{array}{l}\text { Jumlah } \\
\text { Peserta didik }\end{array}$ & Prosentase \\
\hline 1 & $\begin{array}{l}\text { Tuntas } \\
-100\end{array}$ & 15 & $44,18 \%$ \\
\hline 2 & $\begin{array}{l}\text { Tidak } \\
\text { Tuntas } \\
70\end{array}$ & 19 & $55,82 \%$ \\
\hline & Total & 34 & $100,00 \%$ \\
\hline
\end{tabular}

(Sumber: Data Peneliti, 2020)

Dari tabel 1 diatas, diperoleh bahwa hasil belajar peserta didik masih rendah, peserta didik yang telah memenuhi Kriteria Ketuntasan Minimal (KKM) 
sebanyak 15 peserta didik dari 34 peserta didik, bila dipresentasikan sebesar 44,18\%. Peserta didik yang tidak memenuhi batas KKM yaitu sebesar 55,82\%. Rata-rata kelas pada penilaian harian pertama (1) peserta didik tersebut sebesar 61,76.

2. Siklus Tindakan I

Tahap pelaksanaan siklus tindakan I, guru menggunakan model Discovery Learning dengan metode Kooperatif Mind Maping yang terdiri dari 1 kali pertemuan untuk KBM dan 1 kali pertemuan evaluasi siklus I. Siklus I ini dilaksanakan pada tanggal 22 Oktober 2020 dan pada tanggal 29 Oktober 2020. Urutan pelaksanaan tindakan tersebut adalah tahap perencanaan, pelaksanaan, observasi dan evaluasi. Tahap observasi dalam tindakan siklus I, guru mengajar di kelas sesuai dengan perencanaan dan juga melakukan obeservasi penelitian sesuai dengan intrumen observasi penelitian.

Kegiatan pembelajaran yang dilakukan meliputi kegiatan pendahuluan selama 15 menit dengan melakukan apersepsi, motivasi, absensi, pretest, dan juga menjelaskan kegiatan pembelajaran yang akan dilakukan pada pertemuan siklus I. Kegiatan inti dilakukan selama 60 menit dengan melakukan kegiatan pembelajaran sesuai dengan sintaks Discovery Learning yang tertulis dalam RPP yang meliputi memberikan stimulus melalui media video pembelajaran, diksusi kelompok, mengerjakan LKPD, presentasi kelompok, dan juga menyimpulkan dan menguatkan materi diskusi. Kegiatan penutup dilakukan selama 15 menit dengan melakukan kesimpulan, refleksi pembelajaran, evaluasi, dan juga mengingatkan kegiatan untuk pembelajaran pertemuan berikutnya.

Dalam pertemuan kedua siklus I ini dilakukan penilaian terhadap pembelajaran yang sudah dilakukan sebelumnya. Evaluasi pertemuan ini dibagi untuk tiga kegiatan. Pada 30 menit pertama digunakan untuk mengerjakan LKPD, kemudian 30 menit kedua untuk mengerjakan minikuis, dan 30 berikutnya untuk mengerjakan Mind Mapping. Setelah guru membuka pembelajaran dan menjelaskan sedikit tentang tata cara mengerjakan soal evaluasi, kemudiaan guru menganjurkan kepada setiap peserta didik untuk mengerjakan soal evaluasi dengan baik, walaupun hal ini dilakukan secara online karena hal ini akan menjadi acuan guru dalam melihat batas kemampuan pemahaman materi peserta didik dari apa yang sudah dipelajari bersama.

Selanjutnya peserta didik dapat mengerjakan soal yang berupa LKPD yang sudah ditautkan dalam Microsoft Teams melalui menu assignment atau penugasan langsung dikerjakan di word online yang akan otomatis menyimpan dari jawaban 
peserta didik. Bagi yang sudah selesai kemudian bisa dikirim dengan cara klik send atau kirim. Setelah peserta didik selesai mengerjakan LKPD tersebut, guru secara langsung dapat memberikan nilai dan tanggapan kepada hasil yang dikerjakan oleh peserta didik. Selain mengerjakan LKPD, peserta didik juga diminta mengerjakan minikuis yang berupa soal pilihan ganda dengan cara klik link yang sudah ditautkan dalam Microsoft Teams ataupun juga bisa di klik link melalui WhatsApp group kelas sosiologi XI IPS 3. Dalam kegiatan evaluasi ini guru juga masih banyak menjumpai peserta didik yang malas dan seperti enggan untuk mengerjakan soal LKPD serta minikuis. Hal ini dapat dilihat dari status peserta didik yang terdapat dalam penugasan tersebut. Sebagai contoh misalnya apabila statusnya turn in berarti sudah mengerjakan dan sudah dikirim. Bila statusnya not turn in berarti sama sekali belum dibuka dari tugas yang kita kirim ke akun mereka. Apabila view berarti tugas hanya dilihat dan belum dikerjakan dan belum dikirim. Hal ini ditindak lanjuti guru dengan cara menghubungi peserta didik untuk segera mengerjakan tugas dan minikuis tersebut. Guru menghubungi peserta didik melalui menginformasikan di WhatsApp group maupun di WhatsApp secara pribadi. Setelah selesai mengerjakan LKPD dan minikuis guru juga mengingatkan peserta didik untuk mengumpulkan tugas Mind Mapping secara berkelompok yang dapat dikirim melalui WhatsApp ataupun melalui Microsoft Teams yang sudah disediakan.

\section{Grafik 1 Nilai Kognitif, Psikomotor dan Afektif Untuk Pra Siklus dan Siklus I}

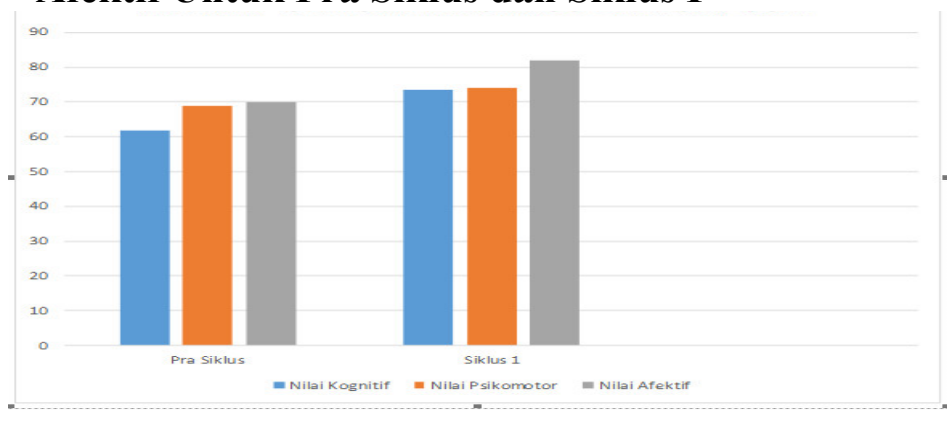

(Sumber: Data Peneliti, 2020)

Deskripsi mengenai hasil penilaian dari sklus I pada grafik dapat lebih jelasnya dilihat dari penjelasan table dibawah ini:

Tabel 2 Hasil Nilai Peserta Didik dari

Siklus I

\begin{tabular}{|l|l|l|l|}
\hline Tindakan & $\begin{array}{l}\text { Rata - } \\
\text { Rata } \\
\text { Nilai } \\
\text { Kognitif }\end{array}$ & $\begin{array}{l}\text { Rata - } \\
\text { Rata Nilai } \\
\text { Psikomotor }\end{array}$ & $\begin{array}{l}\text { Rata - } \\
\text { Rata } \\
\text { Nilai } \\
\text { Afektif }\end{array}$ \\
\hline $\begin{array}{l}\text { Pra } \\
\text { Tindakan }\end{array}$ & 61,76 & 68,82 & 69,85 \\
\hline Siklus I & 73,53 & 74,18 & 81,86 \\
\hline
\end{tabular}

(Sumber: Data Peneliti, 2020)

Dari Tabel 1.2 diatas, diperoleh informasi bahwa proses pembelajaran melalui model Kooperatif Tipe Mind Mapping dengan Aplikasi Microsoft 
Teams sudah diterapkan secara keseluruhan pada siklus pertama dan diakhir siklus diberikan tes akhir siklus I untuk mengetahui adanya peningkatan kemampuan penalaran siswa sebelum diberi perlakuan dan sesudah diberi perlakuan. Adapun hasil tes pada siklus I disajikan pada tabel sebagai berikut:

Tabel 3 Hasil Tes Pada Siklus I

(Sumber: Data Peneliti, 2020)

\begin{tabular}{|l|l|l|l|}
\hline No & Kriteria & $\begin{array}{l}\text { Jumlah } \\
\text { Peserta didik }\end{array}$ & Prosentase \\
\hline 1 & $\begin{array}{l}\text { Tuntas } 70 \\
-100\end{array}$ & 20 & $58,82 \%$ \\
2 & $\begin{array}{l}\text { Tidak } \\
\text { Tuntas } \\
70\end{array}$ & 14 & $41,18 \%$ \\
\hline & Total & 34 & $100,00 \%$ \\
\hline
\end{tabular}

Berdasarkan Tabel 1.3 diatas, memberikan informasi bahwa adanya adanya peningkatan rata-rata siswa sebelum dan sesudah penelitian tindakan kelas menjadi 58,82\%. Jika dilihat dari indikator hasil pada rata-rata hasil tes kemampuan penalaran siswa masih belum mencapai ketuntasan. Hal ini dikarenakan rata-ratanya belum mencapai ketuntasan minimal 70. Juga pada siklus I masih terdapat $41,18 \%$ siswa yang belum memenuhi batas ketuntasan minimal meski rata-rata siswa yang belum tuntas masih pada taraf interval yang normal. Hal ini menunjukkan hasil yang belum optimal sehingga perlu diadakan kembali pembelajaran pada siklus II.
3. Siklus Tindakan II

Tahap pelaksanaan tindakan siklus II, guru menggunakan model Discovery Learning dengan metode Kooperatif Mind Maping seperti pertemuan siklus I yang terdiri dari 1 kali pertemuan untuk kegiatan pembelajaran dan juga untuk evaluasi siklus II. Siklus II ini dilaksanakan pada tanggal 13 November 2020. Urutan pelaksanaan tindakan tersebut adalah tahap perencanaan, pelaksanaan, observasi dan evaluasi. Tahap observasi dalam tindakan siklus II guru mengajar dikelas sesuai dengan perencanaan dan juga melakukan obeservasi penelitian sesuai dengan intrumen observasi penelitian.

Kegiatan pembelajaran yang dilakukan meliputi kegiatan pendahuluan selama 15 menit dengan melakukan apersepsi, motivasi, absensi, pretest, dan juga menjelaskan kegiatan pembelajaran yang akan dilakukan pada pertemuan siklus II. Kegiatan inti dilakukan selama 60 menit dengan melakukan kegiatan pembelajaran sesuai dengan sintaks Discovery Learning yang tertulis dalam RPP yang meliputi dengan memberikan stimulus melalui media video pembelajaran, diksusi kelompok, mengerjakan LKPD, presentasi kelompok, dan juga menyimpulkan serta menguatkan 
materi diskusi. Kegiatan penutup dilakukan selama 15 menit dengan melakukan kesimpulan, refleksi pembelajaran, evaluasi, dan juga mengingatkan kegiatan untuk pembelajaran pertemuan berikutnya.

Penilaian dalam siklus II terhadap pembelajaran dilakukan sama seperti evaluasi pada pertemuan sebelumnya. Evaluasi pertemuan ini dibagi dalam tiga kegiatan. Pada 30 menit pertama digunakan untuk mengerjakan LKPD, kemudian 30 menit kedua untuk mengerjakan minikuis, dan 30 berikutnya untuk mengerjakan Mind Mapping. Setelah guru membuka pembelajaran dan menjelaskan sedikit tentang tata cara mengerjakan soal evaluasi, guru menganjurkan setiap peserta didik untuk mengerjakan soal evaluasi dengan baik, walaupun hal ini dilakukan secara online karena hal ini akan menjadi acuan guru dalam melihat batas kemampuan pemahaman materi peserta didik dari apa yang sudah dipelajari bersama.

Selanjutnya peserta didik dapat mengerjakan soal yang berupa LKPD yang sudah ditautkan dalam Microsoft Teams melalui menu assignment atau penugasan langsung dikerjakan di word online yang akan otomatis menyimpan dari jawaban peserta didik. Bagi yang sudah selesai kemudian bisa dikirim dengan cara klik send atau kirim. Setelah peserta didik selesai mengerjakan LKPD tersebut, guru dapat langsung memberikan nilai dan tanggapan kepada hasil yang dikerjakan oleh peserta didik. Selain mengerjakan LKPD, peserta didik juga diminta mengerjakan minikuis yang berupa soal pilihan ganda dengan cara klik link yang sudah ditautkan dalam Microsoft Teams ataupun juga bisa di klik link melalui WhatsApp group kelas sosiologi XI IPS 3. Dalam kegiatan evaluasi ini guru juga masih banyak menjumpai peserta didik yang malas dan seperti enggan untuk mengerjakan soal LKPD dan juga minikuis. Hal ini dapat dilihat dari status peserta didik yang terdapat dalam penugasan tersebut. Sebagai contoh misalnya apabila statusnya turn in berarti sudah mengerjakan dan sudah dikirim. Bila statusnya not turn in berarti sama sekali belum dibuka dari tugas yang kita kirim ke akun mereka. Apabila view berarti tugas hanya dilihat dan belum dikerjakan dan belum dikirim. Hal ini ditindak lanjuti guru dengan cara menghubungi peserta didik untuk segera mengerjakan tugas dan minikuis tersebut. Guru menghubungi peserta didik melalui menginformasikan di WhatsApp group maupun di WhtsApp group secara pribadi. 
Setelah selesai mengerjakan LKPD dan minikuis guru juga mengingatkan peserta didik untuk mengumpulkan tugas mind maping secara berkelompok yang dapat dikirim melalui whatshap ataupun melalui Microsoft Teams yang sudah disediakan.

Grafik 2 Nilai Kognitif, Psikomotor dan Afektif Untuk Pra Siklus, Siklus I dan

\section{Siklus II}

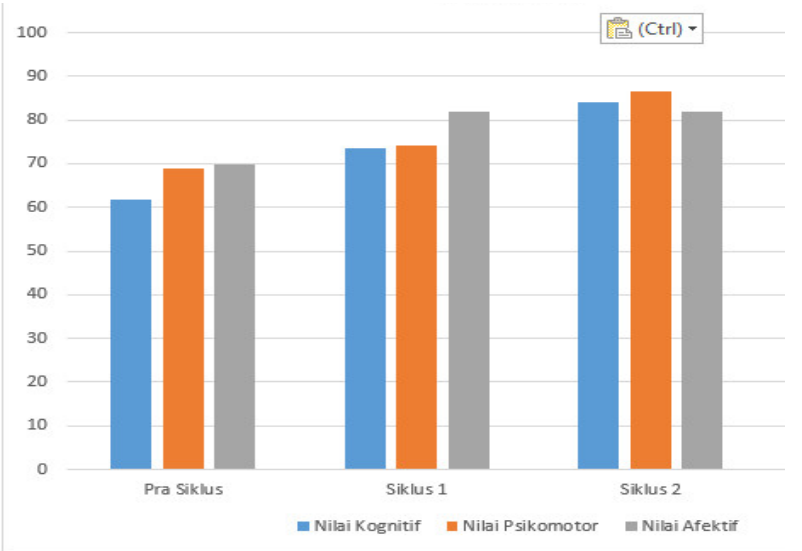

(Sumber: Data Peneliti, 2020)

Deskripsi mengenai hasil penilaian dari sklus II lebih jelasnya dapat dilihat dari penjelasan tabel dibawah ini.

Tabel 4 Hasil Rata - Rata Nilai Peserta Didik Dari Siklus II

\begin{tabular}{|l|l|l|l|}
\hline Tindakan & $\begin{array}{l}\text { Rata } \\
- \\
\text { Rata } \\
\text { Nilai } \\
\text { Kogn } \\
\text { itif }\end{array}$ & $\begin{array}{l}\text { Rata - } \\
\text { Rata Nilai } \\
\text { Psikomotor }\end{array}$ & $\begin{array}{l}\text { Rata }- \\
\text { Rata } \\
\text { Nilai } \\
\text { Afektif }\end{array}$ \\
\hline $\begin{array}{l}\text { Pra } \\
\text { Tindakan }\end{array}$ & 61,76 & 68,82 & 69,85 \\
\hline Siklus I & 73,53 & 74,18 & 81.86 \\
\hline Siklus II & 84,12 & 86,52 & 82,06 \\
\hline
\end{tabular}

(Sumber: Data Peneliti, 2020)

Dari Tabel 4 diatas, diperoleh informasi bahwa proses pembelajaran melalui model Kooperatif Tipe Mind Mapping dengan Aplikasi Microsoft
Teams sudah diterapkan secara keseluruhan pada siklus II, setelah diberikan perlakuan berupa proses pembelajaran melalui model Kooperatif Tipe Mind Mapping dengan Aplikasi Microsoft Teams, kemudian diadakan tes akhir siklus II untuk mengetahui adanya peningkatan rata-rata hasil kemampuan penalaran siswa dari siklu I dengan siklus II dan banyaknya presentase siswa yang tuntas dalam materi masalah sosial. Adapun hasil penilaian peserta didik pada siklus II disajikan pada tabel berikut: Tabel 5 Hasil Tes Pada Siklus II

\begin{tabular}{|l|l|l|l|}
\hline No & Kriteria & $\begin{array}{l}\text { Jumlah } \\
\text { Peserta didik }\end{array}$ & Prosentase \\
\hline 1 & $\begin{array}{l}\text { Tuntas } \\
-100\end{array}$ & 30 & $88 \%$ \\
\hline 2 & $\begin{array}{l}\text { Tidak } \\
\text { Tuntas } \\
70\end{array}$ & 4 & $12 \%$ \\
\hline & Total & 34 & $100,00 \%$ \\
\hline
\end{tabular}

(Sumber: Data Peneliti, 2020)

Berdasarkan Tabel 1.5 diatas, memberikan informasi bahwa adanya peningkatan rata-rata hasil belajar siswa berupa kemampuan penalaran pada siklus II dengan presentas sebesar $88 \%$ dengan jumlah siswa 30 dan yang belum tuntas 4 orang. Secara klasikal hasil belajar berupa kemampuan penalaran siswa pada 
pembelajaran siklus II sudah mencapai target karena melebihi indikator yang ditetapkan yaitu $80 \%$.

Data hasil observasi pada siklus II telah dievaluasi dan mnunjukkan bahwa selama pembelajaran dengan model Kooperatif Tipe Mind Mapping dengan Aplikasi Microsoft Teams pada siklus II tidak terdapat kendala yang berarti dan secara keseluruhan pelaksanaan baik dan lancar. Hal ini dapat dilihat dari indikator keberhasilan hasil belajar siswa dalam pembelajaran melalui model Kooperatif Tipe Mind Mapping dengan Aplikasi Microsoft Teams telah tercapai. Penilaian hasil belajar berupa rata-rata kemampuan penalaran mencapai presentase $88 \%$, hal ini berarti melebihi KKM yang sudah ditentukan yaitu 70 dengan siswa yang tuntas sebanyak 30 orang $(88 \%)$. Ketercapaian hasil belajar kognitif peserta didik dapat dilihat pada tabel berikut:

Tabel 6 Ketercapaian Keberhasilan Siklus II

\begin{tabular}{|l|l|l|l|}
\hline $\begin{array}{l}\text { Aspek } \\
\text { yang } \\
\text { dinilai }\end{array}$ & \multicolumn{2}{|l|}{ Siklus II } & Keterangan \\
\cline { 2 - 3 } & Target & Capaian & \\
\hline $\begin{array}{l}\text { Hasil } \\
\text { Belajar } \\
\text { Kognitif }\end{array}$ & $80 \%$ & $88 \%$ & Meningkat \\
\hline
\end{tabular}

(Sumber: Data Peneliti, 2020)

Dengan demikian penelitian dan observasi memutuskan kemampuan penalaran siswa pada materi masalah sosial meningkat melalui pembelajaran model Kooperatif Tipe Mind Mapping dengan Aplikasi Microsoft Teams sehingga penelitian tindakan kelas diakhiri pada siklus II.

Kemampuan penalaran siswa mengalami peningkatan dari siklus I ke siklus II. Kemampuan penalaran siswa ketika siklus I memperoleh presentase sebesar 58,82\% dan siklus II kemampuan penalaran siswa memperoleh presentase sebesar $88 \%$. Peningkatan presentase hasil penalaran siswa dari pra tindakan ke siklus I ke siklus II dapat dilihat pada Tabel berikut ini:

Tabel 7 Komparasi Hasil Capaian Siklus I dan II

\begin{tabular}{|l|l|l|l|}
\hline $\begin{array}{l}\text { Aspek } \\
\text { yang } \\
\text { dinilai }\end{array}$ & $\begin{array}{l}\text { Siklus } \\
\text { Siklus }\end{array}$ & $\begin{array}{l}\text { Siklus } \\
\text { I }\end{array}$ & \\
\hline $\begin{array}{l}\text { Hasil } \\
\text { Belajar }\end{array}$ & $58,82 \%$ & $88 \%$ & Meningkat \\
Kognitif & & & \\
\hline
\end{tabular}

(Sumber: Data Peneliti, 2020)

Dari tabel 7 diatas, dapat disimpulkan penalaran siswa dengan menerapkan model Kooperatif Mind Mapping dengan Aplikasi Microsoft Teams pada siklus II telah menunjukkan keberhasilan dan telah mencapai indikator keberhasilan yang telah ditentukan. Sehingga kemampuan penalaran siswa siklus II telah mencapai indikator 
keberhasilan sebesar $88 \%$ dan tidak perlu adanya perbaikan serta tindakan untuk siklus selanjutnya.

\section{DISKUSI}

Untuk dapat mencapai harapan yang sesuai dengan keinginan peneliti, dalam penelitian kali ini peneliti melakukan Penelitian Tindakan Kelas (PTK) yang dilaksanakan di kelas XI IPS 3 SMA Negeri 1 Jekulo Kudus dengan menggunakan model Discovery Learning dan metode Kooperatif Mind Maping. Model Discovery Learning dan metode Kooperatif Mind Maping diterapkan kepada peserta didik dengan berdasarkan berbagai masalah yang telah ditemukan peneliti dalam kegiatan observasi. Penerapan model Discovery Learning dan metode Kooperatif Mind Maping ini diharapkan mampu meningkatkan hasil belajar peserta didik dalam mata pelajaran sosiologi.

Dalam pratindakan yang dilakukan di kelas XI IPS 3 SMA Negeri 1 Jekulo Kudus dalam kegiatan observasi masih banyak dijumpai peserta didik yang pasif dalam kegiatan pembelajaran. Kurangnya partisipasi peserta didik tersebut dikarenakan kurangnya keberanian dan rasa percaya diri peserta didik. Pada uji coba pratindakan peserta didik yang belum melampaui KKM yaitu dengan nilai 70 sebanyak 19 peserta didik setara dengan 55,82\% dan peserta didik yang sudah mencapai KKM sebanyak 15 peserta didik setara dengan 44,18\%. Dalam kegiatan pratindakan ini diperoleh nilai rata-rata sebesar 61,76 .

Pada siklus I yang terdiri dari satu pertemuan meliputi tahapan kegiatan pembelajaran dan evaluasi dengan waktu 2x45 menit diperoleh data yaitu. peserta didik yang mencapai KKM berjumlah 20 peserta didik (58,82\%), sedangkan peserta didik yang belum memenuhi KKM sebanyak 14 peserta didik (41,18\%). Nilai rata-rata yang diperoleh peserta didik dalam penerapan Discovery Learning dan metode Kooperatif Mind Maping disiklus I adalah 73,52. Dengan demikian dapat diketahui setelah penerapan Discovery Learning dan metode Kooperatif Mind Maping hasil belajar peserta didik mengalami peningkatan 11,76 dari sebelum tindakan 61,76 meningkat menjadi 73,52 pada siklus I. Dan mencapai target capaian penelitian pada siklus I yaitu 70. Berdasarkan hasil analisis yang telah dilakukan oleh peneliti, dapat diketahui bahwa masih terdapat beberapa kelemahan yang terjadi baik dari guru maupun peserta didik, sehingga guru dan peserta didik memutuskan untuk melakukan siklus II.

Pada siklus II peneliti berusaha memperbaiki kelemahan dari siklus I yang mana diperoleh data peserta didik yang mencapai KKM berjumlah 30 peserta 
didik (88\%). Nilai rata-rata yang diperoleh peserta didik dalam penerapan model Discovery Learning dan metode Kooperatif Mind Maping di siklus II adalah 84,11. Dengan demikian dapat diketahui setelah penerapan model Discovery Learning dan metode Kooperatif Mind Maping hasil belajar peserta didik mengalami peningkatan 10,59 dari siklus I yang hanya 73,52 meningkat menjadi 84,11 pada siklus II. Dan mencapai target capaian penelitian pada siklus II yaitu 80. Berdasasrkan hasil penelitian pada siklus II yang telah mencapai indicator keberhasilan maka tidak perlu adanya perbaikan dan tindakan untuk siklus selanjutnya. Hal ini dibuktikan dengan dilakukannya kegiatan pratindakan, siklus I, dan siklus II yang selalu mengalami peningkatan disetiap tindakan. Begitu pula dalam data disebutkan bahwa pada siklus I ke siklus II nilai peserta didik mengalami peningkatan.

Berdasarkan pembahasan yang telah dipaparkan sebelumnya model Discovery Learning dan metode Kooperatif Mind Maping yang digunakan oleh peneliti sesuai dengan teori belajar kontruktivisme. Budiningsih (Bambang Warsita, 2008 : 78) mengemukakan bahwa peserta didik harus aktif melakukan kegiatan, aktif berpikir, menyusun konsep dan memberi makna sesuatu yang dipelajarinya. Dari pendapat yang dikemukakan Budiningsih tersebut model Discovery Learning dan metode Kooperatif Mind Maping lebih menekankan pembelajaran pada prosesnya bukan hanya hasil dari peserta didik. Teori tersebut relevan dengan tujuan dari penelitian ini karena dalam proses pembelajaran melibatkan aspek afektif dan aspek psikomotorik peserta didik. Dari kedua aspek tersebut berpengaruh langsung terhadap hasil belajar peserta didik.Dari hasil tindakan, pengamatan dan pembahasan dapat ditarik kesimpulan bahwa penerapan model Discovery Learning dan metode Kooperatif Mind Mapping dapat meningkatkan hasil belajar sosiologi materi masalah sosial pada peserta didik kelas XI IPS 3 SMA Negeri 1 Jekulo Kudus tahun pelajaran 2020 / 2021.

\section{KESIMPULAN}

Berdasarkan hasil penelitian tindakan kelas pada pembelajaran dengan penerapan model Kooperatif Tipe Mind Mapping dengan Aplikasi Microsoft Teams pada peserta didik kelas XI IPS 3 SMA Negeri 1 Jekulo Kudus diperoleh hasil pada siklus I dengan nilai rata-rata kelas 73,53 dengan ketuntasan pembelajaran mencapai 58,82\%. 
Sedangkan pada siklus II diperoleh ratarata kelas 84,12 dengan ketuntasan pembelajaran mencapai $88 \%$. Dengan ini dapat disimpulkan bahwa nilai aspek kognitif peserta didik kelas XI IPS 3 SMA Negeri 1 Jekulo Kudus pada siklus I dan siklus II mengalami peningkatan.

\section{DAFTAR PUSTAKA}

Bambang, Warsita.(2008). Teknologi Pembelajaran. Jakarta : Rineka Cipta Esti, Sri. (1989). Psikologi Pendidikan. Jakarta: Grafindo

Lie, Anita. (2005). Cooperative Learning: Mempraktikkan Cooperative Learning Di Ruang Ruang Kelas. Jakarta: PT Grasindo

Mulyatiningsih, Endang. (2011). Riset Terapan Bidang Pendidikan dan Teknik. Yogyakarta: UNY Press

Solihatin, Etin, Raharjo. (2008). Cooperative Learning Analisis Model Pembelajaran IPS. Jakarta: Bumi Aksara

Sudjana, Nana. (2011). Penilaian Hasil Proses Belajar Mengajar. Bandung: PT Remaja Rosdakarya

Susanto Windura. (2008). Mind Map langkah Demi Langkah. Jakarta: PT Elex Media Koputindo

Suharsimi Arikunto, dkk. (2010). Penelitian Tindakan Kelas. Jakarta: Bumi Aksara Tony Buzan. (2005). Buku Pintar Mind Map. Jakarta: PT Gramedia Pustaka Utama Wardani, Naniek Sulistya. 2010. Pengembangan Model Pembelajaran Aktif (Hasil Penelitian). Salatiga: Widya Sari Press 